\title{
Australian Journal of \\ Study of storage condition on the physicochemical properties of biodiesel derived from macaúba palm (Acrocomia aculeata) oil using multivariate analysis
}

\author{
Sônia R. Arrudas ${ }^{1,4^{*}}$, Paulo H. Fidêncio ${ }^{1}$, Flaviano O. Silvério ${ }^{2}$, Maira Martins Franco ${ }^{3}$, Darlyson Santos \\ Silva ${ }^{4}$, Márcio Antônio Silva Pimenta ${ }^{4}$
}

${ }^{1}$ Departamento de Química, Universidade Federal dos Vales do Jequitinhonha e Mucuri, Rodovia MGT 367, Km 583, 5000, Diamantina - MG, Brasil

${ }^{2}$ Instituto de Ciências Agrárias, Universidade Federal de Minas Gerais, ICA, Av. Universitária 1000, 39.404-547

Montes Claros - MG, Brasil

${ }^{3}$ Departamento de Química, Universidade Federal de Uberlândia, Av. João Naves de Ávila, 2121 - Santa Mônica, Uberlândia - MG, 38408-100, Brazil

${ }^{4}$ Departamento de Biologia Geral, Universidade Estadual de Montes Claros, Campus Darcy Ribeiro, Vila Mauricéia, 39401-089 Montes Claros - MG, Brasil

\section{*Corresponding author: sonia.arrudas@unimontes.br}

\begin{abstract}
The influence of storage conditions on the properties of biodiesel from macaúba (Acrocomia aculeata (Jacq.) Lodd. ex Mart). seed oil was evaluated. The biodiesel samples were stored for 12 months at $25^{\circ} \mathrm{C}$ and $4{ }^{\circ} \mathrm{C}$. The physical properties of the biodiesel: acidity index, peroxide and refractive index, flash point, and oxidative stability were determined. The chemical composition of the biodiesel was determined by gas chromatography coupled to mass spectrometry and by infrared spectroscopy. The analysis of the main components and the Hierarchical Analysis were used to group the samples. The oxidative stability of biodiesel, which developed low acid and peroxide indexes, and the ester composition were maintained stable, regardless of the storage method. However, storage at $4{ }^{\circ} \mathrm{C}$ proved to be more efficient in maintaining the characteristics of the biodiesel. The high quality of biodiesel and its stability confirm the potential of the agro-industrial use of biodiesel from Acrocomia aculeata.
\end{abstract}

Keywords: oxidative stability; palm biodiesel; chemical composition; biodiesel; Acrocomia aculeate; chemometrics.

Introduction

The use of renewable energy sources is a growing demand in the world, and studies on biomass sources available for the consolidation of renewable energy programs have been motivated by the production systems to the search for energy inputs (Abdalla, et al. 2008). Biodiesel, a biodegradable fuel produced from fats and oils is not toxic and is environmentally friendly, Pinto, et al. (2005). Currently, Brazil imports much of the diesel oil it consumes. Increasing Brazil's biodiesel production will displace the diesel imports; thereby, saving the country approximately 160 million US dollar if all diesel import is replaced by biodiesel produced in Brazil (GOV 2016).

In the northern region of the State of Minas Gerais, the diversity of native flora is widespread and constitutes an income source for traditional populations. Among the species used, the fruits from palm trees provide several valuable products. The main products of these palm trees are the oil (extracted from the nut) and the cake (the residue resulting from the oil extraction process). In this context, the oil can be used to produce biofuels such as biodiesel and biokerosene, as well as to produce bioethanol (Lima, et al. 2012).

Acrocomia aculeata (jacq.) Lodd. Exmart, Arecaceae, (macaúba) is an arborescent, thorny, species of palm tree, more than 16 meters high that can be found in the tropical and subtropical regions of the Americas (da Motta, et al. 2002), commomly found in the North of the state of Minas Gerais, a region where the cerrado biome is predominant (Oliveira, et al. 2012). The oil extracted from macaúba fruits has considerable economic potential; and in addition to being a species used for ornamentation, natural medicine, and as food ingredient, it has been studied for use in the energy and industrial sectors, including the production of Biodiesel (C. Mazzottini-dos-Santos, et al. 2014). The macaúba is a native and perennial species found in several Brazilian tropical forests. It presents $6,2 \mathrm{Kg}$ oil productivity per hectare competing with established oilseeds such as oil palm. All fruit parts are usable and the seeds present high oil content, which is majoritarian characterized by saturated fatty acids, predominantly lauric acid (Reis, et al. 2017). 
Biodiesel, as well as the vegetable oils, undergoes compositional analysis to detect specific compounds and contaminants. Gas chromatography, usually linked to a mass spectrometer, is the most commonly used for this type of analysis because the quantification of components present in very low concentrations can be accomplished with a high accuracy(de Araujo, et al. 2001, Knothe 2006). The identification of fatty acids, triacylglycerols, acylglycerols, methanol, among others, can be achieved. However, the use of a mass spectrometer is necessary to avoid ambiguities of results because single mass spectrum of each component is obtained (Mariani, et al. 1991, Plank and Lorbeer, 1992).

The evaluation of the oxidative stability is an important factor in the industrial process. This evaluation involves the analysis by infrared, CG-EM (Canha, et al. 2012) and rancimat methods (Yang, et al. 2013). The monitoring of these properties is important to determine the appropriate storage conditions for biodiesel produced from macaúba oil, reduce deterioration processes (Azevedo, et al. 2003, Almeida, et al. 2010) and increase the possibilities of use (Davide, et al. 2003, Lutz, 2005). Inadequate storage time and temperature interfere with biodiesel quality (Sambanthamurthi, et al. 2000). The oil chemical and physical properties monitoring are essential for the biodiesel storage adequate conditions definition, aiming to minimize deterioration processes (Azevedo, et al. 2003, Davide, et al. 2003, Almeida, et al. 2010). The inadequate storage is commonly associated with lipolytic microorganism's proliferation, which promotes triacylglycerol and enzymatic autocatalytic hydrolysis of oils and their derivatives (Sambanthamurthi et al. 2000).

Studies that demonstrate the Macaúba biodiesel physicalchemical properties variations over time are not found in the literature. In this perspective, o the objective of this study was to monitor the physicochemical characteristics and chemical composition of the oil fromAcrocomia aculeata seeds as a function of time and storage conditions $\left(25^{\circ} \mathrm{C}\right.$ and $4{ }^{\circ} \mathrm{C}$ ) during a 12 -month period. All the results obtained were studied through multivariate analysis.

\section{Results and Discussion}

The reaction time of one hour and the temperature of 45 oC was sufficient to obtain a $94.53 \%$ yield of biodiesel from macaúba oil. The physicochemical properties of the biodiesel from macaúba seed oil in the period of 01 to 12 months are presented in Table 1 . The determination of biodiesel properties is important for verification of the quality of the product, as is established by the rules of the National Petroleum Agency (ANP). The quality standards presented in this resolution were based on ASTM D6751(ASTM 2002) and EN 14214 (EN14103 2003). The properties of biodiesel from macaúba seed oil are within the established limits for the acidity index, kinematic viscosity and flash point, even after 12 months of storage under both temperature conditions. These factors confirm the potential of biodiesel from macaúba seed oil for use as a biofuel.

\section{Acidity index}

The level of acidity remained below that established by the ANP when the biodiesel was stored at $4{ }^{\circ} \mathrm{C}$ and at $25^{\circ} \mathrm{C}$. In the case of the biodiesel stored at $25{ }^{\circ} \mathrm{C}$, the acidity increased after 12 months of storage. However, the final acidity index $(\mathrm{M}=0.12 \%)$ was lower than the values established by ANP/2014,(ANP 2014). After 12 months of storage, the values are below the values found by Melo and Souza for biodiesel from seed oil and pulp, respectively (Serqueira, et al. 2015, Souza, et al. 2016). Acidity is an essential factor in the quality control of biodiesel because the presence of free fatty acids, triggers an entire oxidative process of the fuel, causing deterioration of parts, corrosion, incrustations and deposit of waste (Portela, 2011).The hydrolytic or oxidative rancification, the main oxidation mechanism of oils and fats, is associated with the reaction of water or air oxygen with fatty acids, especially unsaturated fatty acids (Bobbio \& Bobbio 1992). The absence of double bonds in the carbonic chain of saturated fatty acids makes them more stable in the face of degradative processes (Reda e Carneiro, 2007). The fatty acid composition of macauba oil is, in higher percentage, saturated fatty acids, with predominant lauric acid.

\section{Peroxide value and oxidative stability index (rancimat)}

The peroxide index is not a property that is reported in the ABNT specifications; however, the oxidation parameter can be evaluated through this analysis (El Boulifi, et al. 2013). In relation to the storage conditions, higher values for the peroxide index were obtained after storage of biodiesel under environmental conditions, when the times 0 and 12 months for the treatments at $4^{\circ} \mathrm{C}$ and $25^{\circ} \mathrm{C}$ are compared $(P$ $<0.00010$ ). These values are lower than those found by Boulif, 2013 for soybean biodiesel (El Boulifi, et al. 2013) probably due to the macaúba biodiesel increased saturated esters composition. The oxidation reactions of macaúba biodiesel during the rancimat analysis occurred after nine hours of treatment, a time greater than that required by the ANP, which is at least eight hours (Table 1). However, there was a decrease in the stability as a function of time, especially when it was stored at 25 ㅇ․ This information is important for the definition of the storage conditions and shelf life of the product.

\section{Refractive index, specific density, and viscosity}

There were no changes in the initial condition with regard to the refractive index of the biodiesel stored at $4{ }^{\circ} \mathrm{C}$ and at 25 ${ }^{\circ} \mathrm{C}$. The specific mass of the biodiesel is in accordance with ANP specifications. It is directly related to the molecular structure of the biodiesel components and can be modified by changes in the structure or oxidative processes during storage of the biodiesel. Viscosity is one of the main parameters for evaluating the quality of biodiesel. There was an increase in viscosity during storage at $4{ }^{\circ} \mathrm{C}$ and at $25^{\circ} \mathrm{C}$, in agreement with Knothe et al., 2005. However, these values are within the limits established by the ANP and are consistent with biodiesel of a similar composition (Souza, et al. 2016).

The degree of saturation and the size of the carbon chain influence the viscosity of the biodiesel. A high viscosity can cause processes of deposition of materials in the engines, cause clogging and decrease the efficiency of the combustion process (Lôbo, et al. 2009). This factor is one reason why viscosity is an mportant parameter for 
Table 1. Physical and chemical properties of macaúba biodiesel before and after storage for 12 months at $4{ }^{\circ} \mathrm{C}$ and at $25^{\circ} \mathrm{C}$.

\begin{tabular}{|c|c|c|c|c|c|}
\hline \multirow[t]{2}{*}{ Properties } & \multirow[t]{2}{*}{ Units } & \multirow{2}{*}{$\begin{array}{l}\text { Time Zero* } \\
\text { Condição Inicial }\end{array}$} & \multicolumn{2}{|l|}{ After 12 months } & \multirow{2}{*}{$\begin{array}{l}\text { ANP 45/2014 } \\
\text { Limit }\end{array}$} \\
\hline & & & $25^{\circ} \mathrm{C}$ & $4{ }^{\circ} \mathrm{C}$ & \\
\hline Acidity index & $\mathrm{mg} \mathrm{KOH} \mathrm{g}^{-1}$ & $0.045 \pm 0.0058^{A}$ & $0.121 \pm 0.010^{\mathrm{Bb}}$ & $0.119 \pm 0.0100^{B b}$ & 0.5 \\
\hline Peroxide index & meq. $1000 \mathrm{~g}^{-1}$ & $1.416 \pm 0.01215^{\mathrm{A}}$ & $2.224 \pm 0.000^{\mathrm{Ba}}$ & $2.0218 \pm 0^{\mathrm{Bb}}$ & $-* *$ \\
\hline Refractive index & - & $1.4302 \pm 0.000^{\mathrm{A}}$ & $1.4322 \pm 0.000^{\mathrm{Aa}}$ & $1.4313 \pm 0 \mathrm{Aa}$ & $* *$ \\
\hline Specific mass & $\mathrm{Kg} \cdot \mathrm{m}^{-3}$ & $927 \pm 0.000^{A}$ & $927 \pm 0.000^{\mathrm{Aa}}$ & $927 \pm 0^{\mathrm{Aa}}$ & $850-900$ \\
\hline Viscosity at $40^{\circ} \mathrm{C}$ & $\mathrm{mm}^{2} \mathrm{~s}^{-1}$ & $4.143 \pm 0.000^{A}$ & $4.272 \pm 0.000^{\mathrm{Ba}}$ & $4.175 \pm 0^{\mathrm{Ba}}$ & 3.0 a 6.0 \\
\hline Oxidative stability & $\mathrm{h}$ & $9.83 \pm 0.233^{A}$ & $3.81 \pm 0.148^{\mathrm{Ba}}$ & $5.98 \pm 0.247^{\mathrm{Bb}}$ & 8 \\
\hline Flash point & ${ }^{\circ} \mathrm{C}$ & $110 \pm 0.000^{A}$ & $110 \pm 0.00^{\mathrm{Aa}}$ & $110 \pm 0^{\mathrm{Aa}}$ & Min. 100 \\
\hline
\end{tabular}

* Time zero: Analysis performed after biodiesel synthesis, before storage, at time zero. **(-) there are no guidelines from the Agencia Nacional de Petróleo, Gás Natural e biocombustíveis. Different superscript letters indicate significant differences by the Tukey test at $5 \%$ confidence level when comparing the storage periods in different temperatures $\left(25{ }^{\circ} \mathrm{C}\right.$ and $\left.4{ }^{\circ} \mathrm{C}\right)$ after storage for twelve months. Capital letters compare storage time after 12 months and baseline condition and lowercase letters compare the storage method (temperature 25 and $4 \stackrel{\circ}{ } \mathrm{C}$ ) after 12 month storage period.
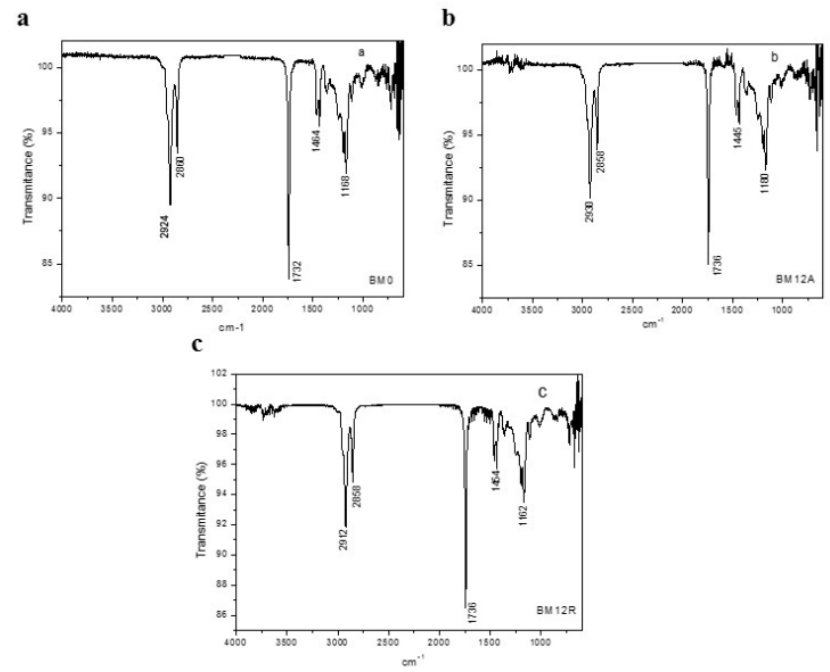

Fig 1. Infrared spectra of the biodiesel from macaúba seed oil. (a) BM0 (macaúba biodiesel time zero); (b) BM12A (macaúba biodiesel stored at $25^{\circ} \mathrm{C}$ for 12 months); (c) BM12R (macaúba biodiesel stored at $4{ }^{\circ} \mathrm{C}$ for 12 months in the refrigerator).

Table 2. Principal esters identified in the analysis of biodiesel from macaúba oil by GC-MS.

\begin{tabular}{lll}
\hline $\mathrm{n} n$ & CCompounds & MS fragments $(\mathrm{m} / \mathrm{z})$ \\
\hline 1 & Methyldodecanoate & $43 / 55 / 74 / 87 / 143 / 171 / 183 / 214$ \\
2 & Methyltetradecanoate & $43 / 55 / 74 / 87 / 143 / 199 / 211 / 242$ \\
3 & Methylhexadecanoate & $43 / 55 / 74 / 87 / 143 / 227 / 239 / 270$ \\
4 & Methyl (9Z, 12Z)-octadeca-9,12-dienoate & $41 / 55 / 67 / 81 / 95 / 109 / 263 / 294$ \\
5 & Methyl (Z)-octadec-9-enoate & $41 / 55 / 69 / 74 / 83 / 97 / 123 / 222 / 265 / 296$ \\
6 & Methyloctadecanoate & $43 / 55 / 69 / 74 / 87 / 129 / 143 / 255 / 298$ \\
\hline
\end{tabular}

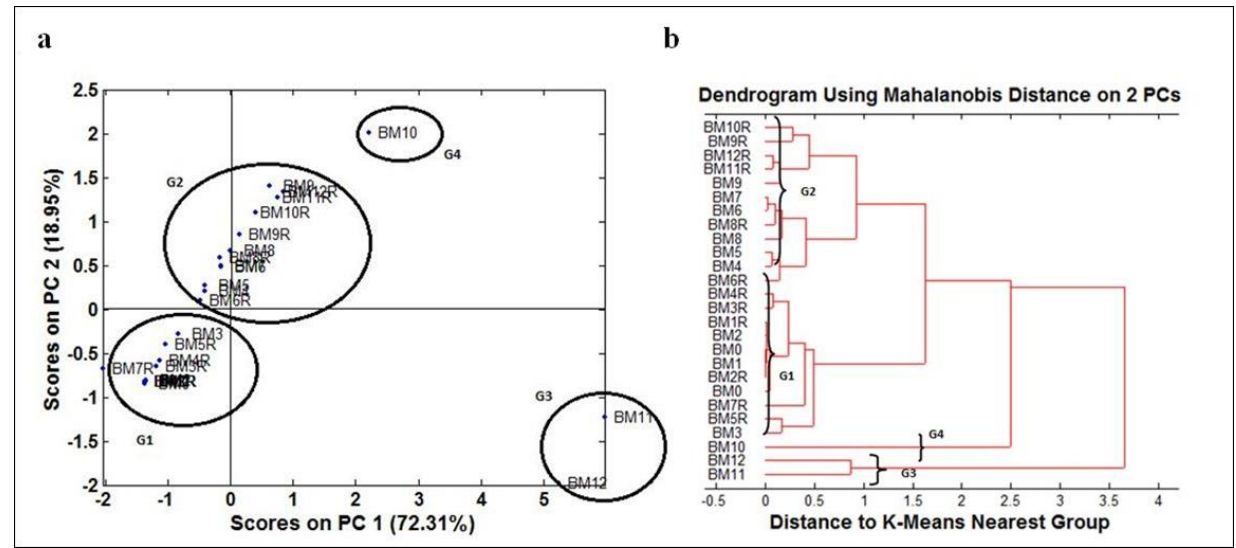

Fig 2. Multivariate analysis of the physical-chemical properties of macauba biodiesel stored at 25 으 and $4 \stackrel{\text { a }}{ }$ ( $\mathrm{BM}$ - macaúba biodiesel stored at $25{ }^{\circ} \mathrm{C}-1$ month up to 12 months and BMR macaúba biodiesel stored at $4{ }^{\circ} \mathrm{C}-1$ month up to 12 ). (a) Dispositions scores of macaúba biodiesel samples analyzed as a function of PC1 (72.31\%) and PC2(18.95\%); (b) Dendrogram of macaúba biodiesel samples, stored at $25 \stackrel{\circ}{ } \mathrm{C}$ and at $4 \stackrel{\circ}{\circ}$. 
Table 3. Relative areas and retention times (RT) of the methyl esters present in the biodiesel produced from macaúba seed oil.

\begin{tabular}{|c|c|c|c|c|}
\hline \multirow{3}{*}{$\begin{array}{l}\text { Ester profile of } \\
\text { Macaúba Biodiesel }\end{array}$} & \multicolumn{4}{|c|}{ Relative area } \\
\hline & \multicolumn{2}{|r|}{$\begin{array}{l}\text { Initial Condition } \\
\text { Time zero* }\end{array}$} & \multicolumn{2}{|c|}{ After 12 months } \\
\hline & $\mathrm{RT}(\mathrm{min})$ & $25 \circ \mathrm{C}$ & $25 \circ \mathrm{C}$ & $4{ }^{\circ} \mathrm{C}$. \\
\hline MethylDodecanoate - Methyllaurate - $\left(\mathrm{C}_{13} \mathrm{H}_{26} \mathrm{O}_{2}\right)$ & 6.348 & 46.7165 & 39.8942 & 40.4470 \\
\hline MethylTetradecanoate - MethylMyristate $\left(\mathrm{C}_{15} \mathrm{H}_{30} \mathrm{O}_{2}\right)$ & 10.263 & 10.7105 & 11.4493 & 11.7282 \\
\hline MethylHexadecanoato - MethylPalmitate $\left(\mathrm{C}_{17} \mathrm{H}_{34} \mathrm{O}_{2}\right)$ & 14.761 & 9.6597 & 9.2757 & 10.1078 \\
\hline Methyl Octadeca-9,12-dienoate - Methyl & 18.508 & 2.5124 & 1.8225 & 1.5618 \\
\hline \multicolumn{5}{|l|}{ Linoleate $\left(\mathrm{C}_{19} \mathrm{H}_{34} \mathrm{O}_{2}\right)$} \\
\hline Methyl Octadec-9-enoate- MethylOleate $\left(\mathrm{C}_{19} \mathrm{H}_{36} \mathrm{O}_{2}\right)$ & 18.688 & 27.4589 & 33.2021 & 32.6128 \\
\hline MethylOctadecanoato - MethylStearate $\left(\mathrm{C}_{19} \mathrm{H}_{38} \mathrm{O}_{2}\right)$ & 19.268 & 2.9420 & 4.3563 & 3.5424 \\
\hline
\end{tabular}
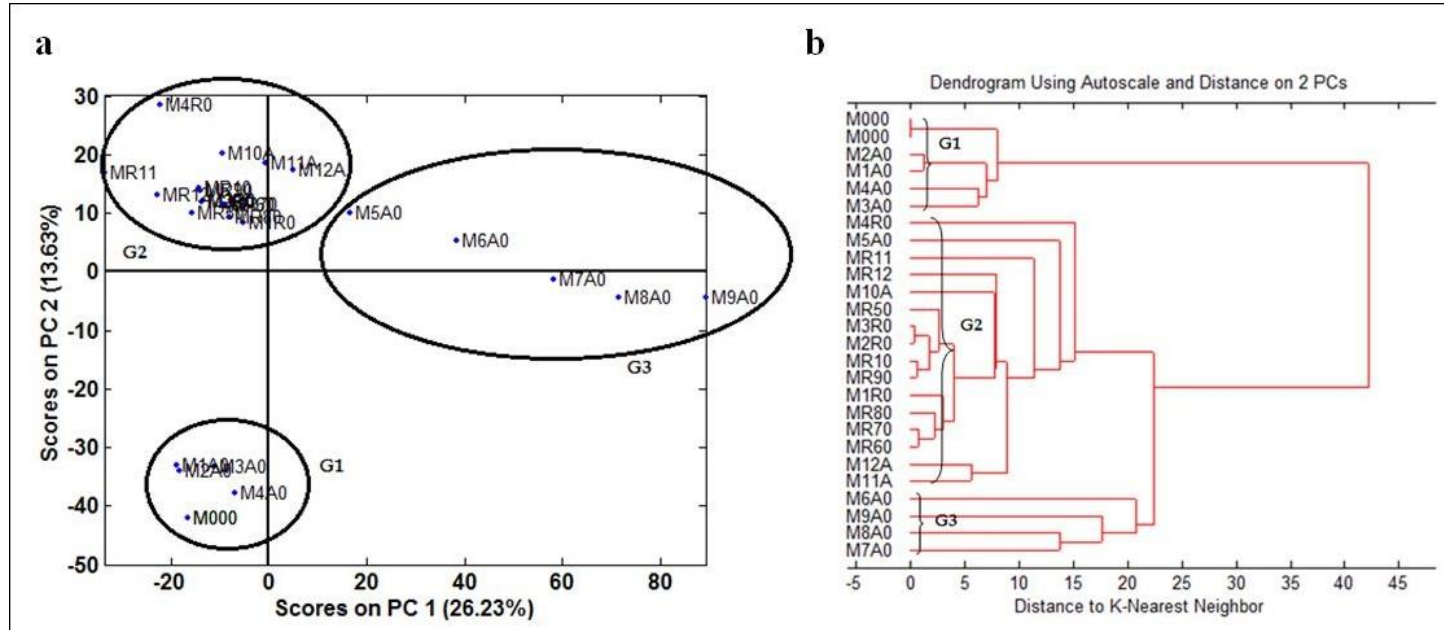

Fig 3. Multivariate analysis of the infrared spectrum of macaúba biodiesel stored at $25 \stackrel{\circ}{ } \mathrm{C}$ and 4 a $\mathrm{C}$. (MA - macaúba biodiesel stored at $25^{\circ} \mathrm{C}-1$ month up to 12 months e MR macaúba biodiesel stored at $4{ }^{\circ} \mathrm{C}-1$ month up to 12 - refrigerator) (a) Dispositions of scores for macaúba biodiesel samples analyzed as a function of PC1 (26.23\%) and PC2(13.63\%). (b) Dendrogram of results for macauba biodiesel samples stored at $25 \circ$ and $4 \stackrel{\circ}{\circ}$.

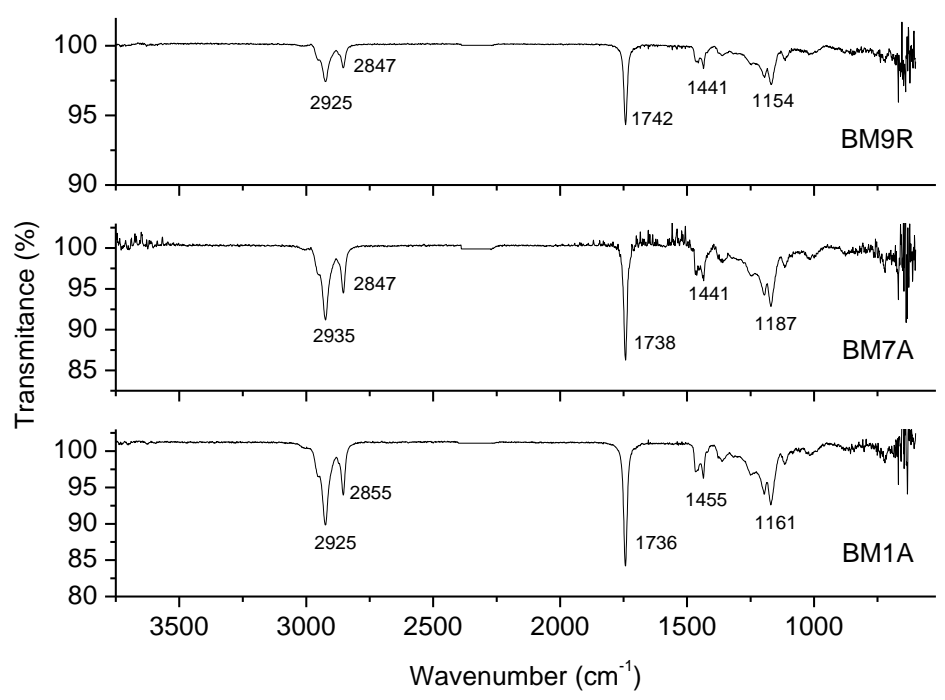

Fig 4. Macaúba seeds oil biodiesel infrared spectra.BM1A, BM7A - (macaúba biodiesel stored at $25{ }^{\circ} \mathrm{C}$ for 1 and 7 months); and BM9R - macaúba biodiesel stored at $4{ }^{\circ} \mathrm{C}$ for 9 months (groups G1, G2 e G3) respectively classified at PCA and cluster analyzes. BM1A and BM9R (macaúba biodiesel stored at 4 으 for 9 months). 
evaluating the quality of the fuel and choosing the most appropriate storage condition.

\section{Flash point}

The flash point of the macaúba biodiesel was $110 \stackrel{\circ}{\circ}$, a

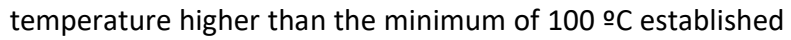
by the ANP. In general, biofuels present less risk of explosion when in contact with air because the flash point is higher than that of diesel (Alcantara, et al. 2000). However, the value found was lower than those found for biodiesel produced from of soybean (178 으) or sunflower (181 $\mathrm{o}$ ) oils (Soriano, et al. 2006), but it is close to the value observed for biodiesel produced from babassu oil (112 으) (de Oliveira Lima, et al. 2007).

\section{Composition of methyl esters}

The compounds detected in the chromatograms are shown in Table 2. The biodiesel (Table 2 and 3) produced from macaúba oil is mainly composed of saturated esters, $56 \%$ of which is methyl dodecanoate (methyl laurate), the principal ester. Being saturated, methyl laurate has a high resistance to oxidation. In the synthesis of biodiesel, short chain saturated fatty acids, such as lauric acid, interact effectively in the transesterification reaction (Ferrari, et al. 2005). However, the cetane index of the fuel is greater because of the lower the degree of unsaturation. Long-chain compounds, such as methyl oleate, which is also present in the fuel, are more susceptible to oxidation and have higher melting points and heats of combustion, characteristics desired in the production of biodiesel.

The predominance of the saturated esters laureate (C 13:0), myristate (C 15:0) and palmitate (C 176:0) was observed. When a higher proportion of unsaturated esters was present, the oxidative stability was lower. The higher percentage of saturated esters present indicates that the macaúba biodiesel has a good stability to oxidation. The storage period did not change the percentage of saturation in the esters present in biodiesel.

\section{Infrared spectroscopy}

In the infrared spectra of the macaúba methyl biodiesel shown in Fig. 1 ( $a, b$ and $c$ ), the principal vibration bands characteristic of asymmetrical and symmetrical stretching can be seen in the region from 2919 to $2849 \mathrm{~cm}^{-1}\left(\mathrm{CH}_{2}\right)$. In the $1732 \mathrm{~cm}^{-1}$ region, the intense band attributed to the $\mathrm{C}=\mathrm{O}$ stretching vibration occurs. A band with an average intensity characteristic of the symmetrical angular $\mathrm{C}-\mathrm{H}$ deformation of the methyl group $\left(\mathrm{CH}_{3}\right)$ occurs at $1432 \mathrm{~cm}^{-1}$. The presence of an absorption band at $1732 \mathrm{~cm}^{-1}(\mathrm{~V} \mathrm{C}=\mathrm{O})$ is characteristic of a saturated aliphatic ester (Silverstein, 2000). This band is associated with the $\mathrm{C}-\mathrm{C}-(\mathrm{C}=\mathrm{O})-\mathrm{O}$ absorption of ester in the 1300 and $1167 \mathrm{~cm}^{-1}$ regions (Díaz-Muñoz, et al. 2016). These characteristics confirm the presence of the saturated ester, methyl dodecanoate, which is the principal component in macaúba methyl biodiesel. There were no significant differences in the infrared spectra of samples submitted to storage at $25^{\circ} \mathrm{C}$ and $4{ }^{\circ} \mathrm{C}$ at 0 and 12 months. The absence of bands in the $3640-3200 \mathrm{~cm}^{-1}$ region, characteristic of free hydroxyl $(\mathrm{O}-\mathrm{H})$ group, was observed in the biodiesel in all the periods and conditions studied.

\section{Multivariate analysis of physicochemical properties}

The scores of the samples in the Principal Components Analysis are represented in Fig. 2a. The physicochemical properties of the macaúba biodiesel samples stored at 25 oC (BM - Macaúba Biodiesel) and at 4 으 (BMR- Refrigerated Macaúba Biodiesel) are arranged in four different groups. This arrangement implies that the samples whose points are close to one another in the Fig. have similar behaviors.

With four main components, it was possible to describe $100 \%$ of the data, most of the information regarding the samples being provided by the variables accumulated in the first two principal components. Principal component 1 (CP1) accumulated $72.31 \%$ of the variance, and the principal component 2 (CP2) accumulated $18.95 \%$ of the variance, to give a total of $91.26 \%$ of the total variance. With regard to the groups formed by G1, G2, G3 and G4, the samples in groups $\mathrm{G} 1$ and $\mathrm{G} 2$ were submitted to storage at $4 \stackrel{\circ}{\circ}$ and 25 o $C$ and were evaluated from 0 to 9 months. The groups $\mathrm{G} 3$ and G4 were composed of only three samples kept at $25 \circ \mathrm{OC}$ and differed from the other groups, indicating that the physical properties of these samples varied after nine months of storage when submitted to the temperature of 25 ㅇ. .

The hierarchical clustering analysis (Fig. 2b) was used to confirm the groups shown in the PCA, in which the samples stored at the temperatures of $4{ }^{\circ} \mathrm{C}$ and $25{ }^{\circ} \mathrm{C}$ were more prevalent in the $\mathrm{G} 1$ and $\mathrm{G} 2$ groups analyzed after nine months of storage. Thus, the groups shown in Fig. 2 depict the similarity of the samples through the smaller distance from one another in the dendrogram. A greater similarity in the characteristics of the samples maintained at $4{ }^{\circ} \mathrm{C}$ and a greater dispersion in the samples maintained at $25^{\circ} \mathrm{C}$ were observed, mainly in relation to the acidity and peroxide index from the tenth month of storage.

The increased acidity and peroxide levels indicate that the biodiesel storage at room temperature favored the methyl esters oxidation. After 9 months storage, it was also verified a decreased oxidative stability with a decrease in the induction period of the samples from groups G3 e G4, varying from 9,83h, 7,05h and 5,98h at time zero, 6 and 12 months respectively. The macaúba seeds biodiesel presents as majority ester the laurate methyl, saturated ester, however, it has reactive species that are susceptible to oxidation as unsaturated and polyunsaturated methyl esters (Lapuerta, et al. 2012) although the oxidative stability depends upon the chemical composition and feedstock used, it will also depend upon the storage conditions. The cluster analyzes classified the more homogeneous groups, corroborating with the statistical results obtained for acidity, peroxide index and oxidative stability, parameters that correspond to sample grouping when statistical differences are observed as a function of time and storage temperature $(\mathrm{P}<0.00010)$.

\section{Multivariate analysis of Infrared analysis results}

The scores in the Principal Components Analysis of the infrared spectra of the samples are represented in Fig. 3a. Each point represents the Fourier transform infrared spectrum. The samples are arranged in three different groups. This fact implies that those samples whose points are close to one another possess a similar behavior, so they 
tend to stay in the same group. It was possible to describe $100 \%$ of the data with nineteen main components. Most of the information regarding the samples are given by the variables accumulated in the first two principal components. Principal component 1 (CP1) accumulated $26.23 \%$ of the variance, and the principal component 2 (CP2) accumulated $13.63 \%$ of the variance, to give a total of $39.86 \%$ of the total variance. The samples belonging to the $\mathrm{G} 2$ group contained all the refrigerated samples. In the other groups, the samples were stored at $25^{\circ} \mathrm{C}$. Those samples whose points are close have a similar behavior. The samples submitted to 4 oC maintain their properties, whereas there is a greater variation in the composition of the samples stored at 25 ㅇ. . The Hierarchical Analysis by Clustering (Fig.3b) was used to confirm the groups as previously shown in the PCA, in which the samples submitted to refrigeration were grouped in group 02, and those stored at $25 \stackrel{\circ}{\circ}$ presented little similarity. These data are in agreement with the clustering of the physicochemical properties. The biodiesel may present oxidative instability, depending on the raw material used for its production. The inadequate storage at $25 \circ \mathrm{C}$ led to oxidative processes because of the action of microorganisms and exposure to heat and humidity (Meher, et al. 2006). Although oxidation cannot be avoided, it can be minimized. Care in the process of synthesis and the use of refrigeration diminish the action of these factors and minimize the processes of deterioration.

The analysis of the infrared spectra (Fig. 4) of samples representative of the groups $\mathrm{G1}, \mathrm{G} 2$ and $\mathrm{G} 3$ classified in the PCA show differences in relation to the bands attributed to the ester stretching and the stimulation of sp3 carbon $\mathrm{CH}$ present in $\mathrm{CH}$ groups, $\mathrm{CH} 2$ and $\mathrm{CH}$ 3. There are also differences in the absorption band around $1465 \mathrm{~cm}-1$ corresponding to the angular deformation band in the plane, symmetrical $\left(\mathrm{CH}_{2}\right)$ and asymmetric $(\mathrm{CH} 3)$. In the region between 1,750-1,740 cm-1, the characteristic $\mathrm{C}=0$ stretch of the ester carbonyl varied among the samples mainly in the G1 group (Silverstein, et al., 2006).

\section{Materials and Methods}

\section{Plant material and oil extraction}

The seeds of mature macaúba fruits were supplied by the UBCM - Unidade Básica de Beneficiamento de Coco Macaúba, located in the community of Riacho D'antas, in Montes Claros in the north of the state of Minas Gerais $\left(16^{\circ} 25^{\prime \prime} 12^{\prime \prime S}-44^{\circ} 18^{\prime \prime} 36^{\prime \prime W}\right)$, Brazil. The seeds were harvested from mature fruits from natural population plants. The seed oil was extracted by the cold extraction method involving pressing with a mechanical press (MP 50 Scoth Tech). The crude oil obtained was centrifuged for 15 minutes at 3500 rpm to remove the impurities.

\section{Biodiesel synthesis}

For the production of biodiesel, $500 \mathrm{~mL}$ of the macaúba seed oil (Acidity value: $0.675 \mathrm{mg} \mathrm{KOH} \mathrm{g}{ }^{-1}$ ) in a $1000 \mathrm{~mL}$, threenecked, round bottom flask was heated to $45{ }^{\circ} \mathrm{C}$ in a water bath.Potassium methoxide solution (the ratio molar oil/methanol was $1: 20$ and $1 \% \mathrm{~m} / \mathrm{m}$ potassium hydroxide) was added, and the reaction mixture was maintained at 45
${ }^{\circ} \mathrm{C}$ under vigorous stirring for one hour in a Fisatom mechanical stirrer Gerhard Knothe, (2010).

The reaction mixture was left in a separatory funnel and allowed to stand for 24 hours for phase separation. Two phases were observed: the upper phase contained the biodiesel, and the lower one contained glycerol, soap, excess base, and alcohol. The lower phase was collected in a 100$\mathrm{mL}$ beaker. The oil was washed with $25 \mathrm{~mL}$ of a $5 \%(\mathrm{v} / \mathrm{v})$ hydrochloric acid in the separatory funnel and left to stand for $1.5 \mathrm{~h}$. The aqueous phase was transferred to a becker, the oil was again washed with $25 \mathrm{~mL}$ of $5 \%(\mathrm{v} / \mathrm{v}) \mathrm{HCl}$, and then washed twice with $20 \mathrm{~mL}$ of saturated $\mathrm{NaCl}$ solution and once with distilled water. The $\mathrm{pH}$ of the last wash was neutral. The solution was transferred to an Erlenmeyer flask and dried over $10 \mathrm{~g}$ of anhydrous sodium sulfate. After 45 minutes, the mixture was filtered and placed in a volume meter. The biodiesel synthesis method aforementioned was described by Knothe and cols(Gerhard Knothe, 2010). All the reagents used were analytical grade (Synth).

\section{Biodiesel analyzes and storage conditions}

The biodiesel was stored in amber glass vials at $4{ }^{\circ} \mathrm{C}$ and 25 ${ }^{\circ} \mathrm{C}$. The acidity index, peroxide index, viscosity and refractive index were analyzed before storage (time zero) and every 30 days for 12 months. The samples were identified with the following description: BM - biodiesel samples from macaúba stored in the environment at $25 \circ \mathrm{O}, \mathrm{BMR}$ - biodiesel samples stored in the refrigerated at 4 으. The numbering $1,2,3, \ldots$, to 12 , refers to the storage time, for example BM9R (biodiesel sample of macaúba chilled for 9 months). The chemical composition was also evaluated by infrared spectroscopy and gas chromatography coupled to mass spectrometry. The oxidative stability and flash point were evaluated using the Rancimat method at time zero and after six and twelve months of storage.

\section{Characterization of the biodiesel}

The characterization of biodiesel was accomplished through the determination of acidity and peroxide and refractive indices, in accordance with the methods of the (AOCS 1998). The determination of the flash point was performed according to the specifications of NBR14598 of $12 / 2012$ (ABNT).

A Brookfield Model LVDV-III + spindle S 63 viscometer at 250 rpm was used for the determination of the viscosity of the macaúba biodiesel. The sample was heated to $40{ }^{\circ} \mathrm{C}$. For the conversion of the dynamic viscosity to kinematic viscosity, the sample density was determined using a 25-mL volumetric pycnometer, with three replications. The analysis of oxidative stability was performed according to EN 14112 in a MetrohmRancimat 873 operated with the assistance of Rancimat 873 Control software (EN14103 2003).

\section{Methyl ester profile}

Chromatographic analysis of the methyl ester profile was performed using an Agilent Technologies (GC 7890A) gas chromatograph coupled to a mass spectrometer detector (MS 5975C) and equipped with a DB-5MS capillary column (Agilent Technologies, $30 \mathrm{~m}$ long $\times 0.25 \mathrm{~mm}$ internal diameter $\times$ 0, $25 \mu \mathrm{m}$ film thickness). Helium (99.9999\% 
purity) was used as the entrainment gas at a rate of $0.8 \mathrm{~mL}$ $\mathrm{min}^{-1}$. Using an autoinjector (CTC combiPaL), $1 \mu \mathrm{L}$ of the sample was injected into the chromatograph at a split ratio of 1:10. The split/splitless injector was maintained at $240{ }^{\circ} \mathrm{C}$. The chromatographic column was initially maintained at 150 ${ }^{\circ} \mathrm{C}$ for $2 \mathrm{~min}$ and then heated at a rate of $4{ }^{\circ} \mathrm{C} \mathrm{min}^{-1}$ to $300{ }^{\circ} \mathrm{C}$, where the temperature was maintained for 2 minutes (post run). The interface temperature was maintained at $260{ }^{\circ} \mathrm{C}$. Ionization was achieved by electron impact at $70 \mathrm{eV}$. The ion source was maintained at $230{ }^{\circ} \mathrm{C}$, and the data acquisition was performed in the full scan mode in the $30-600(\mathrm{~m} / \mathrm{z})$ range. Identification of the compounds detected in the samples was performed by comparison with spectral data from the NIST 2.0 library.

\section{Infrared spectroscopic analysis}

Biodiesel samples were analyzed by infrared spectroscopy in an Agilent Technologies Cary 640 model FTIR spectrophotometer, with a resolution of $2 \mathrm{~cm}^{-1}$, using 16 scans in a range of $4000-600 \mathrm{~cm}^{-1}$, and a germanium ATR crystal. The infrared analyzes were performed to identify modifications on biodiesel functional groups over time, such as $\mathrm{C}=\mathrm{O}$ and $\mathrm{C}-\mathrm{C}-(\mathrm{C}=\mathrm{O})-\mathrm{O}$.

\section{Multivariate analysis}

These data, except for the analysis of oxidative stability, were processed by the chemometric programs contained in the "PLS Toolbox" package, which operates in the MATLAB ${ }^{\circledR}$ environment. The data obtained from the analyses (both physical-chemical and FT-IR) mentioned above were arranged in two $26 \times 6$ matrices (physicochemical parameters); 26 (samples) x 3528 (spectral points, absorbance), in which the samples were arranged in rows and the variables were arranged in the columns in the matrix. The matrix was then subjected to Principal Component Analysis (PCA) and Hierarchical Cluster Analysis (AHA).

\section{Conclusion}

The properties of methyl biodiesel from the oil of macaúba seeds are in agreement with the parameters established by the ANP. The yield of the macaúba methyl biodiesel was greater than $90 \%$, and methyl laurate $(46 \%)$ was the principal ester. The storage time exerted no significant influence on the composition of the biodiesel or its properties. A greater stability was observed when it was stored at $4{ }^{\circ} \mathrm{C}$. These results show that a variability exists in the production of macaúba biodiesel. The composition of the biodiesel confers a high oxidative stability, making its insertion into the industrial process possible. The biodiesel samples from different storage times were grouped by PCA and HCA analyses. Such results may be important when evaluating the stability and oxidative behavior of biodiesel.

\section{Funding}

This work was supported by funds from the Fundação de Amparo à Pesquisa do Estado de Minas Gerais (FAPEMIG).

\section{Acknowledgements}

The authors are grateful to a PCRH scholarship (Programa de Capacitação de Recursos Humanos - Universidade Estadual de Montes Claros) and the Graduate Program in Biofuels of the Federal University of the Jequitinhonha and MucuriValleys.

\section{Conflicts of interest}

The authors declare that no conflicts of interest exist.

\section{References}

Abdalla, AL, Silva Filho, JC, Godoi, AR, Carmo, CA, \& Eduardo, J LP (2008) Utilização de subprodutos da indústria de biodiesel na alimentação de ruminantes. Revista Brasileira de Zootecnia. 37(spe), 260-268.

ABNT. "NBR 14598:2012 2012:20." Retrieved August 11th, 2016, from https://www.abntcatalogo.com.br/norma.aspx?ID=19349 7

Alcantara R, Amores J, Canoira L, Fidalgo E, Franco MJ, Navarro A (2000) Catalytic production of biodiesel from soy-bean oil, used frying oil and tallow. Biomass and Bioenergy. 18(6): 515-527.

Almeida, FAC, Jerônimo E S, Alves NMC, Gomes JP, Silva AS (2010) estudo de técnicas para o armazenamento de cinco oleaginosas em condições ambientais e criogênicas. Revista Brasileira de Produtos Agroindustriais. 12(2): 189202.

ANP (2014) "Agência Nacional do Petróleo, Gás Natural e Biocombustíveis. Resolução no 45 de 25 de agosto de 2014 - Biodiesel." Retrieved July, 2017, from www.anp.gov.br.

AOCS (1998) Official methods and recommended praticces of the American Oil Chemists Society, Champaing.

ASTM (2002) Standard specification for biodiesel fuel blend stock (B100) for middle distillate fuels, American Society for Testing and Materials. D6751-02.

Azevedo MRQA, Gouveia JPG, Trovao DMM, e Queiroga VP (2003) Influência das embalagens e condições de armazenamento no vigor de sementes de gergelim. Revista Brasileira de Engenharia Agrícola e Ambiental. 7: 519-524.

Bobbio PA, Bobbio FO (2001) Química do processamento de alimentos. 3 ed. São Paulo: Varela. 2001. 143 p

Canha N, Felizardo P, Menezes JC , Correia MJN (2012) Multivariate near infrared spectroscopy models for predicting the oxidative stability of biodiesel: Effect of antioxidants addition. Fuel. 97: 352-357.

Davide AC, Carvalho LR, Carvalho MLM, Guimarães RM (2003) Classificação fisiológica de sementes de espécies florestais pertencentes à família lauraceae quanto à capacidade de armazenamento. CERNE. 9(1): 029-035.

de Araujo AJ, Lordello ALL, Maia BHLS (2001) Análise comparativa dos óleos essenciais de folhas e galhos de ocotea puberula (lauraceae). Visão Acadêmica. 2(2): 81-84. de Oliveira Lima JR, Silva RB, Silva CCM, Santos LSS, Santos Junior JR, Moura EM, Moura CVR (2007) Biodiesel de babaçu (Orbignya sp.) obtido por via etanólica. Quim. Nova. 30(3): 600-603. 
Díaz-Muñoz LL , Bonilla-Petriciolet A, Reynel-Ávila H.E., Mendoza-Castillo DI (2016) Sorption of heavy metal ions from aqueous solution using acid-treated avocado kernel seeds and its FTIR spectroscopy characterization. Journal of Molecular Liquids. 215: 555-564.

El Boulifi N, Bouaid A, Martinez M, Aracil J (2013) Optimization and oxidative stability of biodiesel production from rice bran oil. Renewable Energy. 53: 141147.

EN14103 (2003). Fatty acid methyl esters (FAME) Determination of ester and linolenic acid methyl esters contents European Committee for Standardization: Brussels.

Ferrari RA, Oliveira VS, Scabio A (2005). Biodiesel de soja : taxa de conversão em ésteres etílicos, caracterização físico-química e consumo em gerador de energia. Química Nova. 28: 19-23.

Gerhard Knothe, JK (2010). The biodiesel handbook. 1rd edn. GOV (2016). "Ministério de Minas e Energia ". Retrieved October 1st, 2016, from http://www.mme.gov.br/.

Knothe G (2005) Dependence of biodiesel fuel properties on the structure of fatty acid alkyl esters. Fuel Processing Technology. 86(10): 1059-1070.

Knothe G (2006) Analyzing biodiesel: standards and other methods. Journal of the American Oil Chemists' Society. 83(10): 823-833.

Lapuerta M, Rodríguez-Fernández J, Ramos A, Álvarez B (2012) Effect of the test temperature and anti-oxidant addition on the oxidation stability of commercial biodiesel fuels. Fuel. 93(Supplement C): 391-396.

Lima ILP, Scariot A, de Medeiros MB, Sevilha AC (2012) Diversidade e uso de plantas do Cerrado em comunidade de Geraizeiros no norte do estado de Minas Gerais, Brasil. Acta Botanica Brasilica. 26(3): 675-684.

Lôbo IP, Ferreira SLC, Cruz RS (2009) Biodiesel: parâmetros de qualidade e métodos analíticos. Química Nova. 32(6): 1596-1608.

Lutz, IA (2005). Normas analíticas, métodos químicos e físicos para análises de alimentos.1 $1^{a}$ edição digital

Mariani C, Bondioli P, Venturini S, Fedeli E (1991) Vegetable oil derivatives as diesel fuel. Analytical aspects. Note 1: Determination of methyl esters, mono-, di-, and triglycerides.

Mazzottini-dos-Santos HC, Ribeiro LM, MercadanteSimões MO (2014) Floral structure in Acrocomia aculeata (Arecaceae): evolutionary and ecological aspects. Plant Syst Evol. 301: 1425-1440

Meher LC, Vidya Sagar D, Naik SN (2006) Technical aspects of biodiesel production by transesterification-a review. Renewable and Sustainable Energy Reviews. 10(3): 248-268.
Motta PEF, Curi N, Oliveira-Filho AT, Gomes JBV (2002) Ocorrência da macaúba em Minas Gerais: relação com atributos climáticos, pedológicos e vegetacionais. Pesquisa Agropecuária Brasileira. 37(7): 10123-11031.

Oliveira DA, Melo Júnior AF, Brandão MM, Rodrigues LA, Menezes EV, Ferreira PR (2012) Genetic diversity in populations of Acrocomia aculeata (Arecaceae) in the northern region of Minas Gerais, Brazil. Genet Mol Res. 11(1): 531-538.

Pinto AC, Guarieiro LLN, Rezende MJC, Ribeiro NM, Torres EA, Lopes WA, Pereira PAP, Andrade JB (2005) Biodiesel: an overview. Journal of the Brazilian Chemical Society. 16(6B): 1313-1330.

Plank C, Lorbeer E (1992) Quality control of vegetable oil methyl esters used as diesel fuel substitutes: Quantitative determination of mono-, di-, and triglycerides by capillary GC. Journal of Separation Science. 15(9): 609-612.

Portela FM (2011) Efeito da catálise ácida e alcalina na produção e propriedades físico-químicas do biodiesel metílico de pinhão manso. 2011. Dissertation (Masters in Química) - Federal University of Uberlândia, Uberlândia.

Reda SY, Carneiro PIB (2007) Óleos e gorduras: Aplicações e implicações. Revista Analytica. 27: 60-67.

Reis EF, Pinto JFN, Assunção HF, Silva DFP (2017) Genetic diversity of macaúba fruits from 35 municipalities of the state of Goiás, Brazil. Pesquisa Agropecuária Brasileira. 52: 277-282.

Sambanthamurthi R, Sundram K, Tan YA (2000)Chemistry and biochemistry of palm oil. Prog Lipid Res. 39(6): 507558.

Serqueira DS, Dornellas RM, Silva Leandro G, de Melo PG, Castellan A, Ruggiero R, Richter E M, Munoz RAA (2015) Tetrahydrocurcuminoids as potential antioxidants for biodiesels. Fuel. 160(Supplement C): 490-494.

Silverstein, RM et al. (2006). Identificação Espectrométrica de Compostos Orgânicos, LTC.7a ed.

Silverstein, RMW, Francis X, Kiemle, DJ (2000) Identificação Espectrométrica de Compostos Orgânicos. Rio de Janeiro.7ạ edição

Soriano NU, Migo VP, Matsumura M (2006) Ozonized vegetable oil as pour point depressant for neat biodiesel. Fuel. 85(1): 25-31.

Souza GK, Scheufele FB, Pasa TLB, Arroyo PA, Pereira NC (2016) Synthesis of ethyl esters from crude macauba oil (Acrocomia aculeata) for biodiesel production. Fuel. 165: 360-366.

Yang Z, Hollebone BP, Wang Z, Yang C, Landriault M (2013) Factors affecting oxidation stability of commercially available biodiesel products. Fuel Processing Technology. 106: 366-375. 